
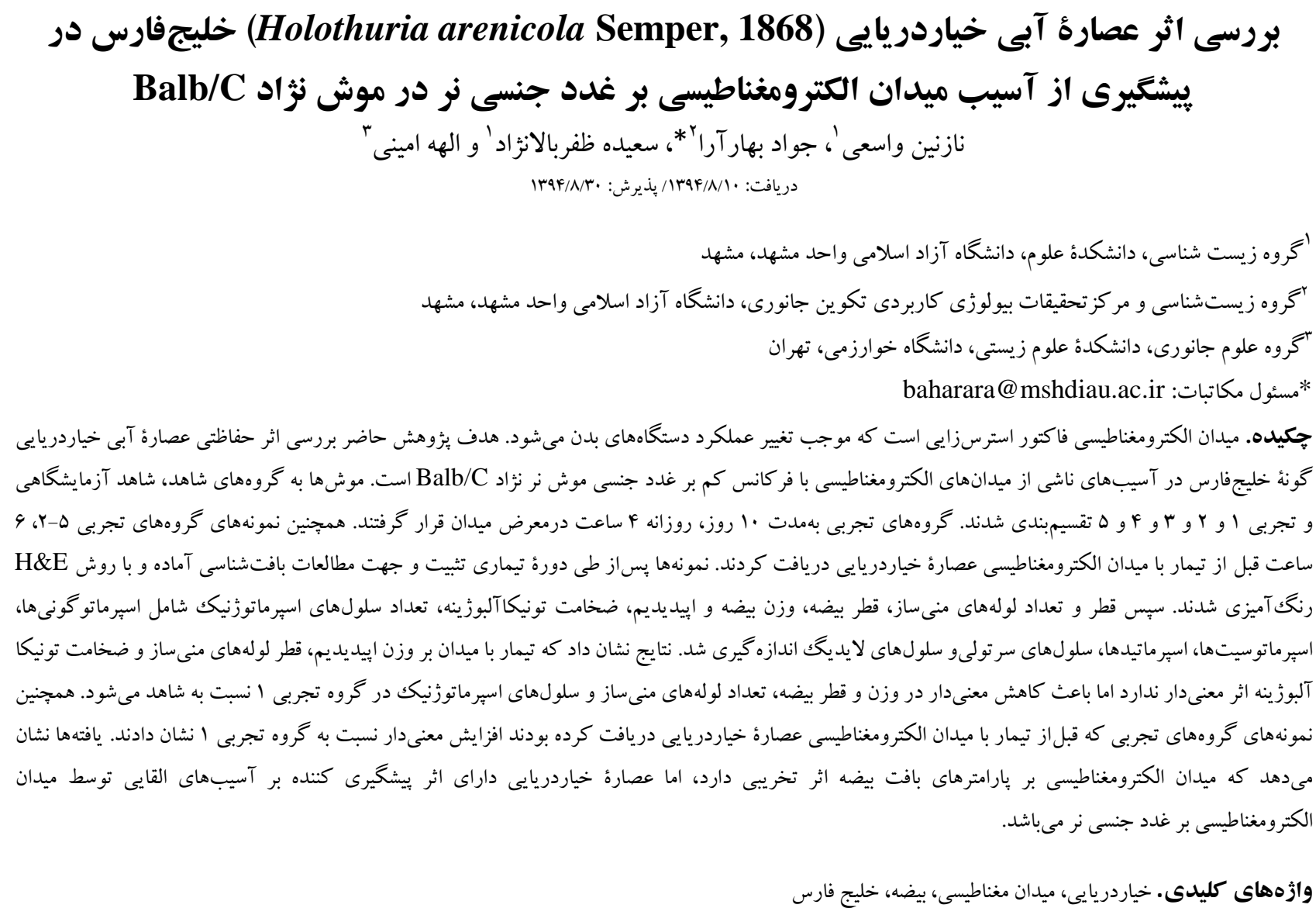

\title{
An investigation of the protective impact exerted by aqua extract of Persian Gulf sea cucumber (Holothuria arenicola Semper, 1868) against damages induced by electromagnetic field on male gonads of Balb/C mice
}

\author{
Nazanin Vasei ${ }^{1}$, Javad Baharara ${ }^{2 *}$, Saeedeh Zafar Balanezhad ${ }^{1}$ and Elaheh Amini ${ }^{3}$ \\ Received 01.11.2015 / Accepted 21.11.2015
}

\author{
${ }^{1}$ Department of Biology, Faculty of Sciences, Mashhad Branch, Islamic Azad University, Mashhad, Iran \\ ${ }^{2}$ Research Center for Animal Development Applied Biology and Biology Department, Mashhad Branch, Islamic Azad \\ University, Mashhad, Iran \\ ${ }^{3}$ Department of Animal Sciences, Faculty of Biological Sciences, Kharazmi University, Tehran, Iran \\ *Correspondent author: baharara@mshdiau.ac.ir
}

\begin{abstract}
Electromagnetic field is a stress factor which can interfere with the functions of body organs. This study aims to evaluate the protective impact of the aqua extract of Persian Gulf sea cucumber on damages induced by low frequency electromagnetic field in male gonads of Balb/C mice. Mice were divided into control, sham-exposed and 5 experimental groups. The experimental groups were then exposed to electromagnetic field (for 10 days and 4 hours per day). Experimental groups 2-5 also received extract of sea cucumber (6h before electromagnetic field). The samples were fixed for histological studies and stained by $\mathrm{H} \& \mathrm{E}$ method. The measurement of the diameter and number of seminiferous tubules, testis diameter, testis and epididymis weight, tunica albuginea thickness, the number of spermatogenic cells including spermatogonia, spermatocytes, spermatids, Sertoli cells and Leydig cells was then executed. The results showed that the impact of electromagnetic field exposure was not significant on epididymis weight, seminiferous tubules diameter and tunica albuginea thickness, while its impact on the reduction of the testis diameter and weight, the number of seminiferous tubules and spermatogenic cells was significant in experimental group 1. In addition, the experimental groups pre-treated with sea cucumber extract indicated significant increment, as compared with experimental group 1.The results proved the destructive effect of electromagnetic field on testis tissue parameters, while sea cucumber extract prevents damages induced by electromagnetic field on male sexual glands of mice.
\end{abstract}

Keywords. sea cucumber, electromagnetic field, testis, Persian Gulf 
تحقيقات نشان داده است كه امواج مايكروويو بر تخمدان و

بارورى در موش ماده تأثير مخربى دارد ( Baharara et al.,

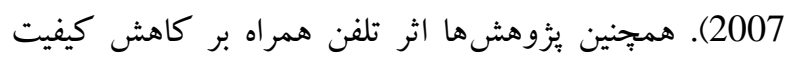

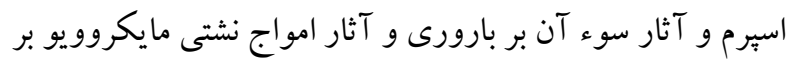

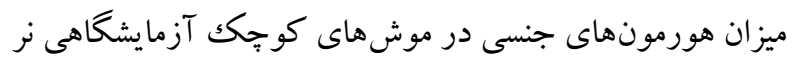

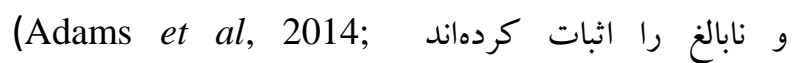
.Gherardini et al., 2014)

ازاينرو اخيراً تلاش براى شناسايى تركيباتى كه بتواند از آثار آسيبرسان ميدانهاى الكترومغناطيسى جلو گيرى كنند، مورد-

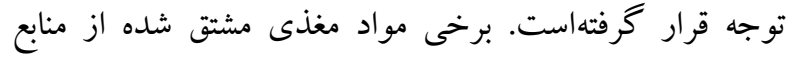
طبيعى بلويزٔه گياهان در جلو گيرى از آسيبهاى توليدمثلى القا-

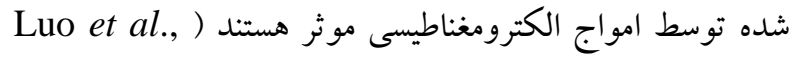
. (2014

تابهال مطالعات اندكى درباب اثر حفاظتى فراوردههاى طبيعى دريايى بر آسيب القاشده ازطريق ميدانهاى الكترومغناطيسى

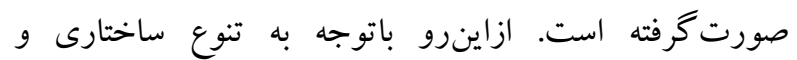
عملكردى فراورده هاى طبيعى دريايى شناسايى تركيبات موثر در زمينه بيشخيرى از آسيبهاى القايى توسط ميدانهاى الكترومغناطيسى حائز اهميت است.

خيارهاى دريايى يكى از موجودات دريايى از شاخهُ خاريوستان و رده خيارسانان با بوست جرمى و بدن زلاتينى هستند كه در كشورهاى جنوبشرقى آسيا براى درمان برخىاز بيمارىها از -

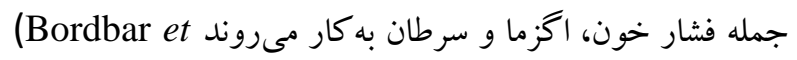

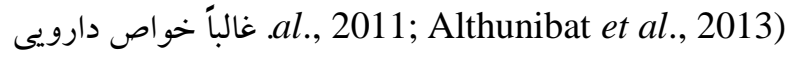
و زيستى خياردريايى به دليل حضور طيف وسيعى از مواد فعال زيستى به ويزه كليكوزيدهاى ترى ترينى (سايونين)، كندروئئين

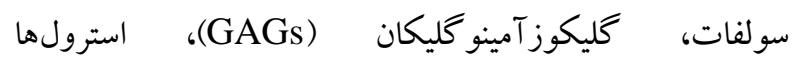
(كليكوزيدها و سولفات)، فنوليككها، سربروزيدها، ييتيدها،

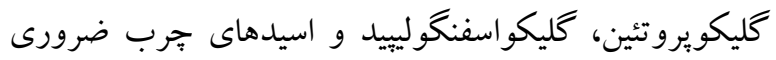

است (Soltani et al., 2015; Baharara et al., 2016). باتوجه به خواص دارويى زيستى خياردريايى و اهميت

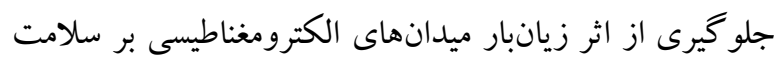

نابارورى غالباً باعث ايجاد مشكلات روانى -اجتماعى و اقتصادى

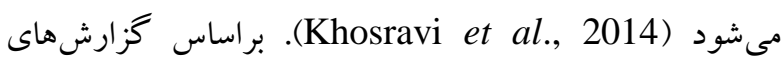

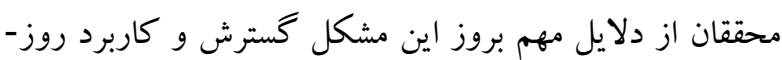

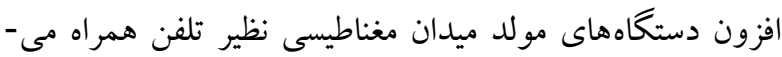
باشد (Baharara et al., 2007). در طول قرن بيستم قرار گرفتن درمعرض ميدان الكترومغناطيسى

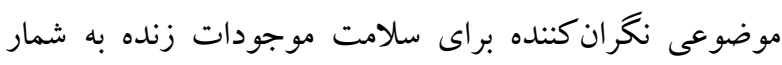

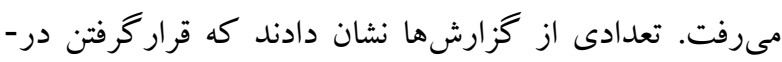

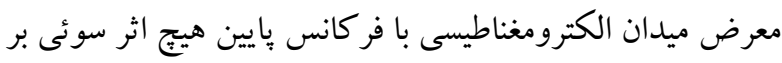

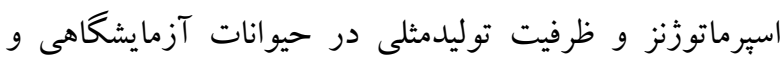
انسان ندارد، درحالى كه برخى مطالعات نشان دادند كه ميدان

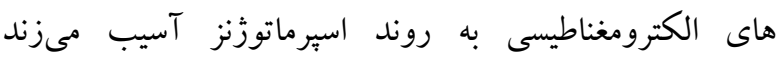
.(Roshangar \& Hamdi, 2014) تحقيقاتى كه درباب آثار مختلف ميدان الكترومغناطيسى انجام

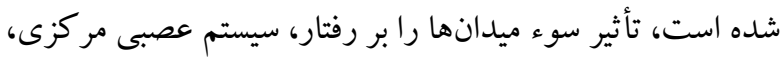
خواب، سيستم قلبى و عروقى و عملكرد سيستم ايمنى اثبات

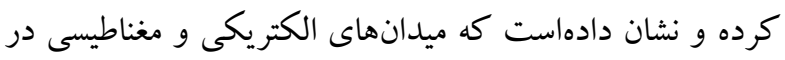
سطوح زيستمحيطى ممكن است طول عمر راديكالهاى آزاد را افزايش دهد و در نتيجه به DNA ريس آسيب برساند .(Roshangar \& Hamdi, 2014)

در اين ميان آسيب به دستخاه توليدمثل يكى از بيامدهاى منفى احتمالى امواج الكترومغناطيسى است و محققان بيشنهاد كردهاند كه آسيب به DNA اسبرماتوزو آى انسانى، يكى از عواقب قرار -

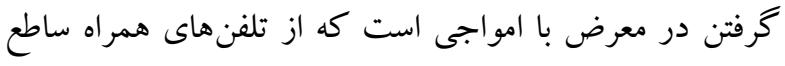
مىشود (Kumar \& Shukla, 2014). خطر ناشى از يرتوهاى الكترومغناطيس بر فرايند توليدمثل به صورتهاى كاهش

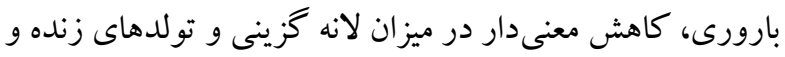

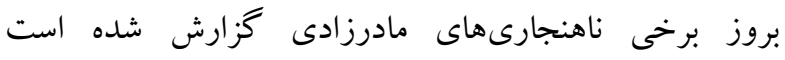

.(Hemayatkhah Jahromi et al., 2012) 
از رابطه B= بnI يبيجيده شده است (B= شدت ميدان مغناطيسى

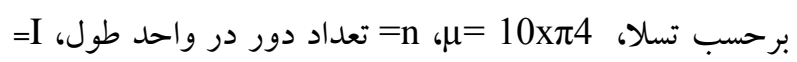
شدت جريان). همجنين از رئوستا براى ايجاد تغيير مقدار جريان v) و خازن با ظرفيت بالا براى جلو گيرى از خودالقائى دستگاه خازن با ظرفيت ·ب ميكروفاراد) استفاده شد ( , Baharara et al.,

. (2006

جهت انجام اين بثوهش، موشها به طور تصادفى به هفت گروه هشت تايى زير تقسيم شدند:

كروه شاهد كه در آن موشها بهطور طبيعى در درون اتاق يرورش حيو انات نخهدارى شدند؛ گرووه شاهد آزمايشگاهى به مدت •ا روز و هر روز بهمدت F ساعت در درون دستخاه مولد ميدان به حالت خاموش قرار گرفتند؛ گروه تجربى ا كه بهمدت . 1 روز و هر روز بلمدات F ساعت درمعرض ميدان الكترومغناطيس با فر كانس •ه هرتز با شدت ... F كاوس قرار

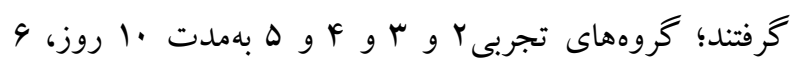
ساعت قبل از ميدان بهترتيب عصاره خياردريايى با دوزهاى هر

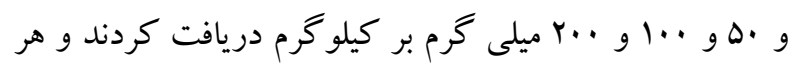

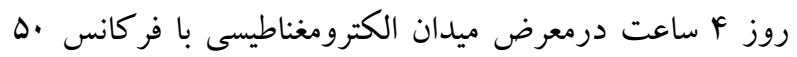

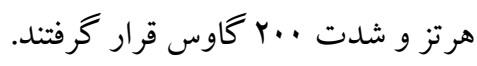

بساز پِايان تجربيات موشها با اتر (Merck, Germany) بيهوش شدند و سبس اييديديم و بيضهها جدا و هركدام به تفكيك توزين شدند. سبس بيضه ها جهت بررسىهاى بافت-

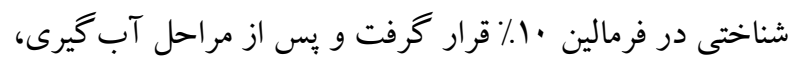

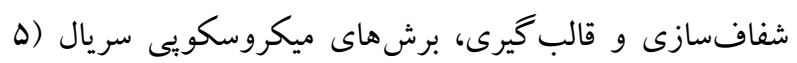
ميكرومتر) از بيضه تهيه و بهوسيلة هماتو كسيلين -ائوزين رنگكآميزى شد. قطر بيضه، وزن بيضه و اييديديم، تعداد و قطر لولههاى منىساز، ضخامت تونيكا آلبوزينه، تعداد اسيرماتو گونى ها،

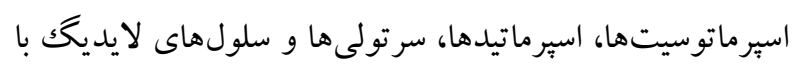
روش شمارش سلولى در ميدانهاى ديدى كه به طور تصادفى از Image J. روى لامها انتخاب شده بودند توسط نرم افزار نرم تعيين شد. جهت انجام اين بزُوهش تجربى بروتكل اخلاق كار با حيوانات در تمام مر احل كار رعايت كرديد.
موجودات زنده در مطالعهُ حاضر اثر حفاظتى خياردريايى در برابر آسيبهاى ناشى از ميدانهاى الكترومغناطيسى با فر كانس كم بر غدد جنسى نر موش كو جُك آزمايشگاهى نزاد Balb/C بررسى شده است.

مواد و روشها

براى تهية عصاره خياردريايى گونهُ خليجفارس (Holothuria (arenicola بدن خشك شد. سيس هر گرم يودر ديوارهُ بدن خياردريايى با •ا ميلى ليتر متانول مطلق (Merck, Germany) مخلوط و بر روى شيكر (Heidolph, Germany) قرار داده شد. عصاره با استفاده از كاغذصافى واتمن لا فيلتر و صاف و سانتريوفيوز شد و سيس عصاره تا زمان خشك شدن درون آون ( Memmert, قرار داده شد. (USA

براى انجام اين مطالعه تجربى آزمايشگاهى، از

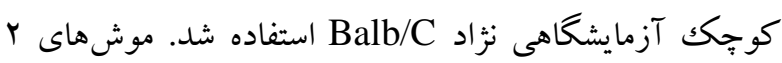

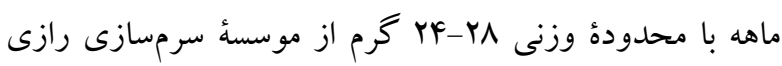
مشهد خريدارى و تا شروع آزمايش بهمنظور تطابق با شرايط به-

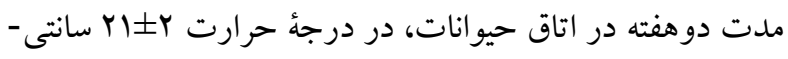

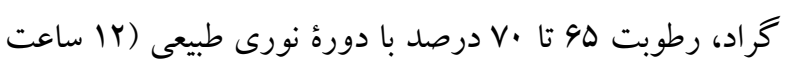
نور و rا ساعت تاريكى) در قفسهاى ويثهاى با دوبار شستوشو و ضدعفونى در هفته، نخهدارى و آب و غذاى كافى در اختيار آنها قرار داده شد.

در اين بيزوهش از دستگاه مولد فر كانس پياين •ه هرتز كه در وضعيت عادى مقادير زيادى از اين ميدانها در محيط وجود داشته، موجب تحريكات عصبى مىشد و بدن تحت تأثير اين امواج قرار مى گيرد، استفاده شد (Parivar et al., 2011). براى توليد ميدان الكترومغناطيس با فركانس كم لازم از مدار ويثه مولد ميدان الكترومغناطيس با فركانس •ه هرتز و شدت

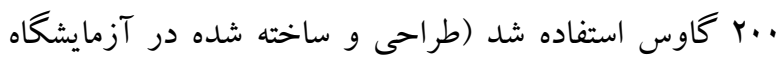
تحقيقاتى زيستشناسى تكوينى دانشگاه آزاد اسلامى مشهد به كوشش بهار آرا و اشرف). اين دستگاه شامل بوبين، لم رئوستا، خازن و آميرمتر است. بوبين از مقادير مناسبى سيم مسى تشكيل كه حول يكك لوله از جنس PVC باتوجه به محاسبه انجام شده 
دار بين گروههاى تجربى ب و ب و F و ه در مقايسه با گروه

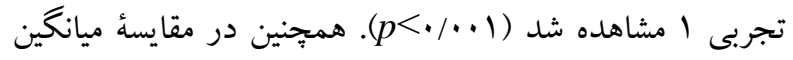

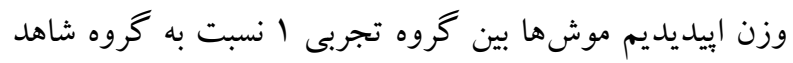

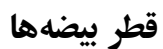

تحليل آمارى، اختلاف معنىدارى بين ميانكين قطر بيضه بين

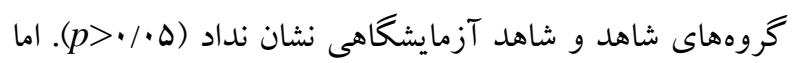
دادههاى كمى با استفاده از نرمافزار SPSS، نسخه 19، تحليل واريانس يككطرفه و تست تعقيبى توكى در سطح معنىدارى نها

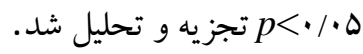

ميانخين قطر بيضه در گروه تجربى انسبت به شاهد كاهش

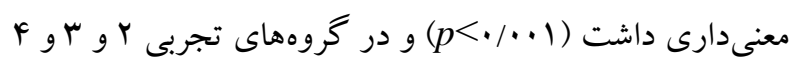
و ه نسبت به گروه تجربى ا افزايش معنىدار قطر بيضه مشاهده

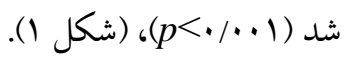

تحليل آمارى بين گروههاى شاهد و شاهد آزمايشگاهى اختلاف

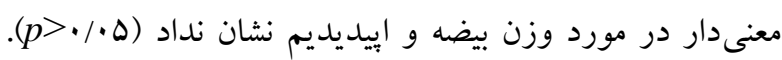

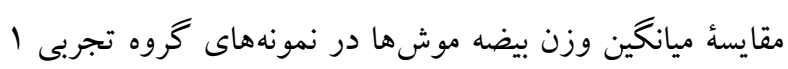

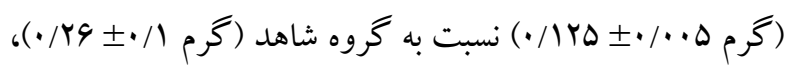

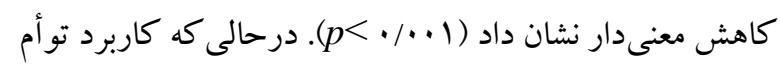

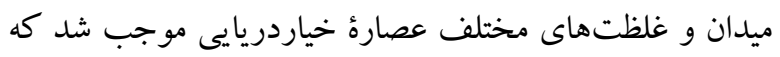

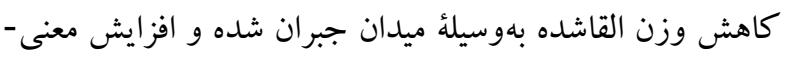

جدول ا- ميانكين وزن بيضه و ايبديديم برحسب گرم.

Table 1. The average weight of the testis and epididymis (in grams).

\begin{tabular}{|c|c|c|}
\hline إيديديم (گرم) & بيضه (كرم) & متغير ها \\
\hline$\cdot / / Y^{ \pm} \cdot / \cdot \cdot \wedge$ & $\cdot / / 9 \pm . / 11$ & شاهد \\
\hline$\cdot / 1 \pm \cdot / \cdot \wedge \wedge$ & $\cdot / r \Delta \pm . / .1$ & شاهد آزمايشكاهى \\
\hline$\cdot / / r \pm \cdot / \cdot 1$ & $\cdot / / \Gamma \Delta \pm \cdot / \cdot \Delta^{* * * * *}$ & كروه تجربى 1 \\
\hline$\cdot / / F \pm \cdot / \cdot 1$ & $\cdot / Y 4 \pm \cdot / 1^{* * * *}$ & كروه تجربى r \\
\hline$\cdot / r \pm \cdot / . . F$ & $\cdot / \pi f \pm \cdot / \cdot 1 * * *$ & كروه تجربى r \\
\hline$\cdot / / r \pm \cdot / \cdot 1$ & $\cdot / Y Y \pm \cdot / 1^{* * * * *}$ & Fروه تجربى F \\
\hline$\cdot / / F \pm \cdot / \cdot 1$ & $\cdot / \pi r \pm \cdot / 1^{* * * * *}$ & كروه تجربى ه \\
\hline
\end{tabular}




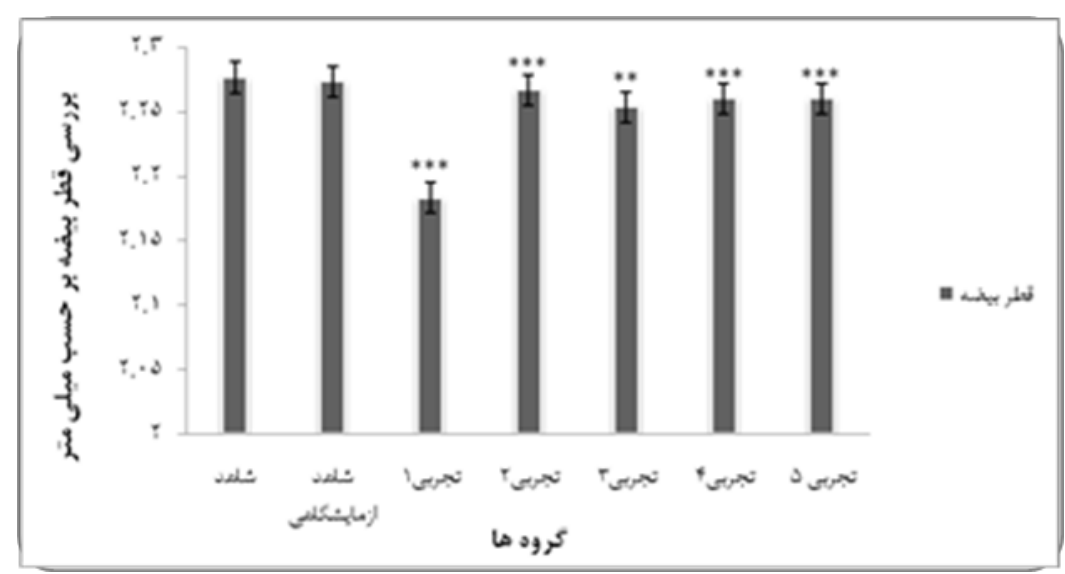

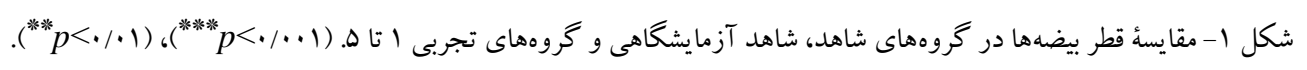

Fig. 1. Comparing the diameter of testis in control, sham and experimental groups of $1-5$. (**p $\left.{ }^{*} \leq 0.01,{ }^{* * *} p \leq 0.001\right)$.

\section{بروسى ضخامت تونيكا آلبوزينه}

اندازه گيرى ضخامت تونيكاآلبوزينه در مقاطع بافتى بيضه در

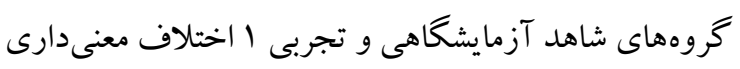

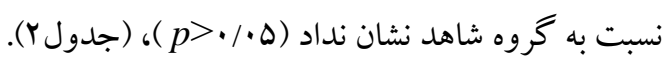

\section{قطر لولهاى منى ساز}

بررسى مقايسهاى نتايج آمارى اختلاف معنى دار در ميانكين قطر

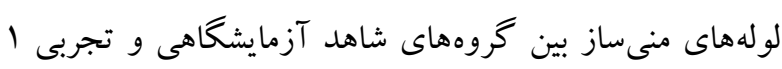

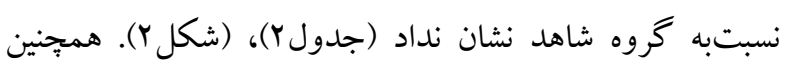

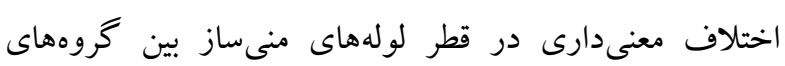

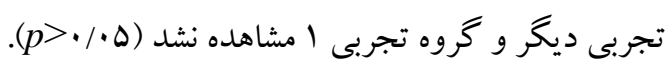

$$
\text { جدول r-بررسى قطر لوله منىساز و ضخامت تونيكا آبوزينه. }
$$

\begin{tabular}{|c|c|c|}
\hline ضخامت تونيكاآلبورينه ( & قطر لوله منىساز (رm) & متغير ها \\
\hline 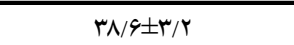 & $|V+/ r \pm 1| / F$ & 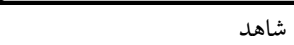 \\
\hline$r q \pm r / q$ & $|V F \pm| F / \mid$ & شاهد آزمايشكاهى \\
\hline$\curlyvee \wedge \pm \cdot / \Lambda$ & $109 \pm 9 / 4$ & تجربى 1 \\
\hline$r \cdot / 9 \pm F / 4$ & $10 \wedge \pm 9 / 9$ & تجربى r \\
\hline$r \mu / 9 \pm r / \Lambda$ & $100 / 9 \pm 1 Y / 9$ & تجربى r \\
\hline$\pi / / 9 \pm \Delta / 4$ & $10 / r \pm 9 / 9$ & تجربى F \\
\hline$r r \pm r / v$ & $|\kappa r / 9 \pm 1| / \cdot 1$ & تجربى ه \\
\hline
\end{tabular}

Table 2. Evaluation the diameter of seminiferous tubules and the thickness of tunica albuginea. 


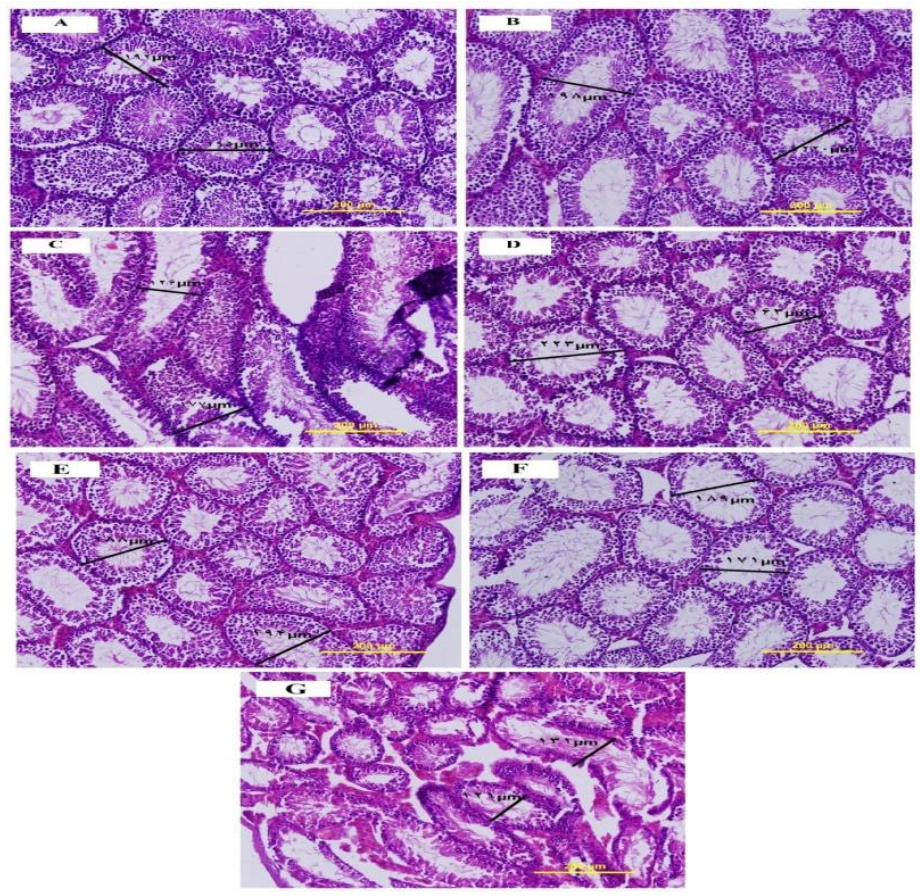

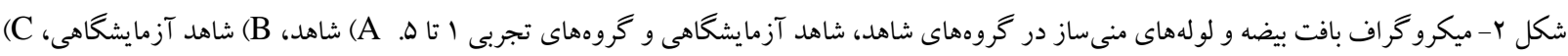

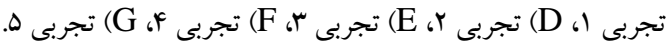

Fig. 2. Testis tissue and seminiferous tubules micrographs in control, sham and experimental groups 1-5: A) control, B) sham, C) experimental 1, D) experimental 2, E) experimental 3, F) experimental 4, G) experimental 5.

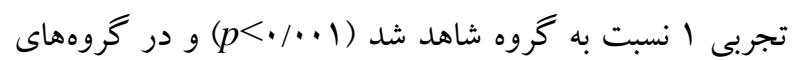
تجربى ץ (1/ ) مختلف عصاره خياردريايى) نسبت به گروه تجربى 1 افزايش معنى دارى در تعداد لولههاى منىساز مشاهده شد (جدول).

\section{تعداد لوله هاى منى}

بررسى آمارى ميانگين تعداد لولههاى منىساز بين گروههاى شاهد و شاهد آزمايشگاهى اختلاف معنى دارى نشان ندان نداد

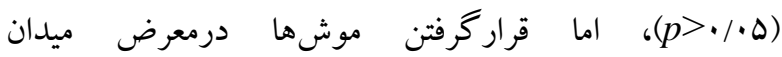
الكترومغناطيسى موجب كاهش معنى دارى تعداد لوله ها در گروه

جدول r- شمارش لوله هاى منى ساز.

Table 3. Seminiferous tubules enumeration.

\begin{tabular}{|c|c|}
\hline $191 / 9 \pm 1 / r$ & شاهد \\
\hline $\mid \Lambda \Delta / 9 \pm r / \varphi$ & شاهد آزمايشَاهى \\
\hline $109 \pm \cdot / \Lambda^{* * * * *}$ & تجربى 1 \\
\hline $19 V / r \pm 1 / 9$ & تجربى r \\
\hline $199 / 9 \pm 1 / 9^{* * *}$ & تجربى r \\
\hline $199 / 9 \pm r / \cdot 0^{* * * * *}$ & تجربى F \\
\hline $19 \Delta / \Upsilon \pm \Upsilon / \Lambda^{* * * * *}$ & تجربى ه \\
\hline
\end{tabular}


شمارش تعداد سلولهاى اسبرماتوسيت در گروههاى تجربى Y و تعداد سلولهاى اسير ماتوزنيك

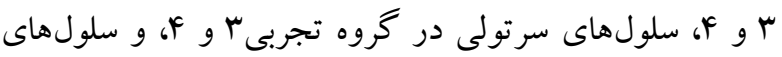

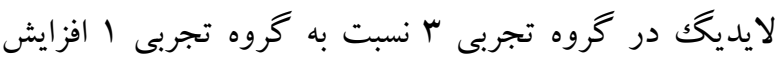

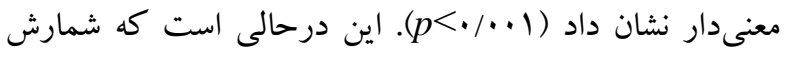

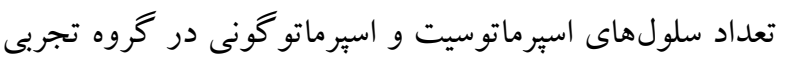
ه، سلولهاى سرتولى در گروه تجربى ب و سلولهاى لايديخك

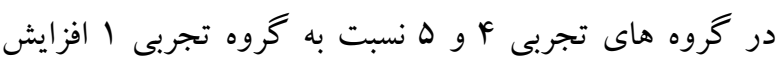

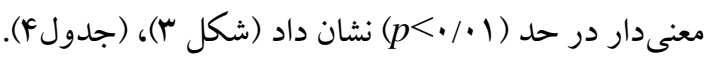

تعداد اسبرماتو گونى ها، اسِرماتوسيتها، اسبرماتيدها، سلولهاى

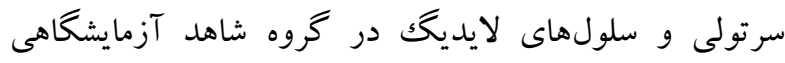

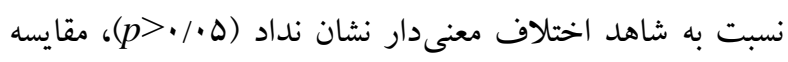
با گروههاى ديخر نشاندهندة كاهش معنىدار تمامى سلولهاى

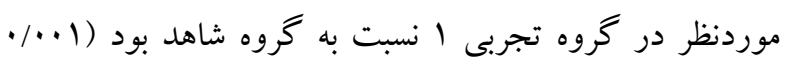

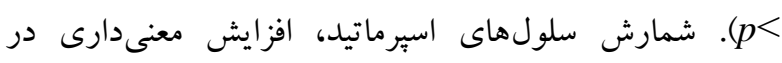

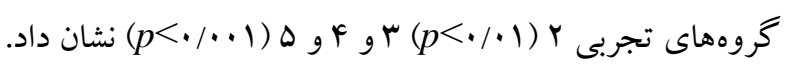
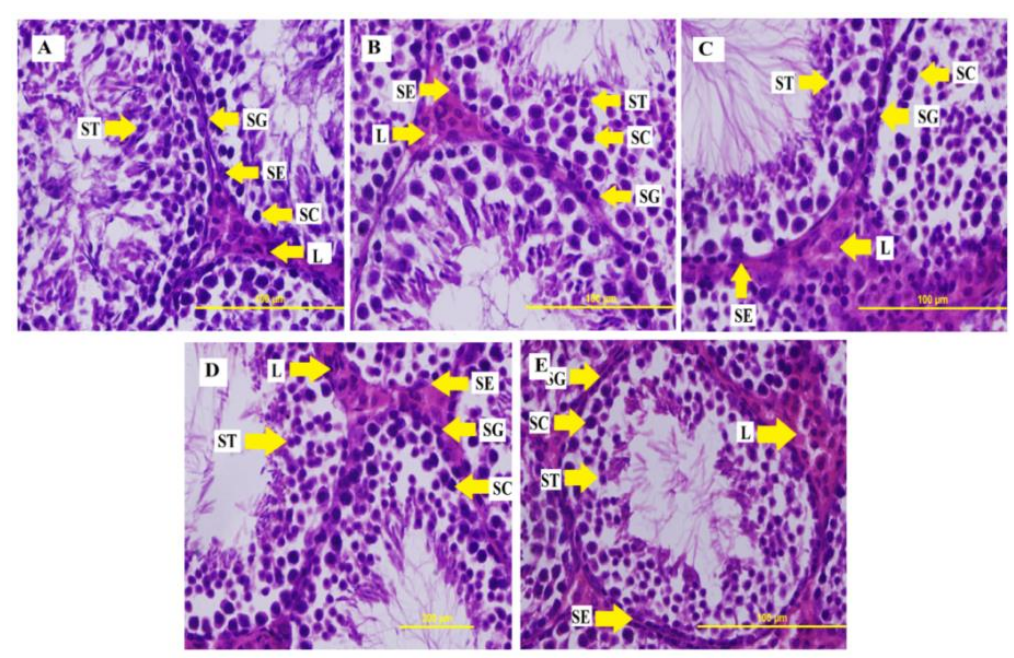

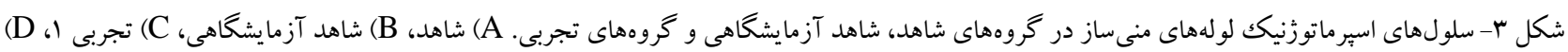

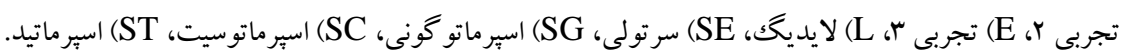

Fig. 3. Seminiferous tubules spermatogenic cells in control, sham and experimental groups: A) control, B) sham, C) the experimental 1, D) the experimental 2, E) the experimental 3, L) leydig, SE) sertoli, SG) spermatogonium, SC) spermatocyte, ST) spermatid.

$$
\text { جدول F- تعداد سلولهاى اسيرماتوزنيك. }
$$

Table 4. Number of spermatogenic cells.

\begin{tabular}{|c|c|c|c|c|c|}
\hline اسبرماتيد & اسبرماتوسيت & اسبرماتو گونى & سرتولى & لايديگك & \\
\hline$W V / 9 \pm r / 9$ & $91 / 9 \pm r / 1$ & $\kappa q \pm \cdot / \wedge$ & $\mid f \pm \cdot / \Lambda$ & $r r / G \pm r / \cdot \Delta$ & شاهد \\
\hline$V Q / r \pm 1 / r$ & $q \cdot / r \pm 1 / r$ & $\mathrm{FV} \pm \cdot / \Lambda$ & $11 / 9 \pm 1 / 4$ & $r \mathrm{r} \pm \cdot / \Lambda$ & شاهد \\
\hline$\kappa Y / r \pm G / r^{* * * * *}$ & $\kappa \psi / 9 \pm 1 / r^{* * * * * * *}$ & 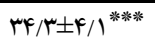 & $9 / \Gamma^{\prime} \pm 1 / r^{* * * * * *}$ & $1 Y / 9 \pm 1 / 9^{* * * * * *}$ & تجربى 1 \\
\hline$\Lambda \cdot / 9 \pm r / \cdot q^{* * * *}$ & $94 / 9 \pm r / . q^{* * * * * *}$ & $r 9 / 9 \pm 1 / r$ & $11 \pm \cdot / \Lambda^{*}$ & $10 \pm \cdot / 1$ & تجربى r \\
\hline$\wedge q \pm Y / 9^{\text {****\% }}$ & $9 \Delta / r \pm r / \cdot 0^{* * * * *}$ & $r q \pm \cdot / \wedge$ & $\mid r / r \pm 1 / r^{\text {****** }}$ & $r \mid / 9 \pm 1 / r^{\text {****** }}$ & تجربى r \\
\hline$M \pm 1 / 9^{* * * * * *}$ & $\Delta q \pm F /$ N $^{\text {*** }}$ & $r \varphi / 9 \pm r / 9$ & $1 r / 9 \pm 1 / r^{* * * * * * *}$ & $19 \pm \cdot / \Lambda^{* * *}$ & تجربى F \\
\hline$\Lambda r / 9 \pm 9 / q^{* * * * *}$ & $\Delta \wedge \pm Y / \Upsilon^{* * *}$ & $k q \pm \cdot / \Lambda^{* * * *}$ & $1 \cdot / 9 \pm 1 / r^{*}$ & $r \cdot \pm 1 / 9^{* * *}$ & تجربى ه \\
\hline
\end{tabular}


زيانبار ميدانهاى الكترومغناطيسى بر بافت بيضه را اثبات كردهـ-

است (Baharara et al., 2007). Parivar موشهاى بالغ درمعرض ميدان الكترومغناطيسى با فر كانس بايين موجب تغييراتى در اسيرماتوزنز از جمله افزايش تعداد اسيرماتوسيت هاى ثانويه، ايجاد حالت سن سيتيوم در سلولهاى اسبرماتوزنيك و تخريب بافت بينابينى بيضه شده كه مى تواند به كاهش بارورى در موشهاى نر منجر شود. تجربة حاضر نيز

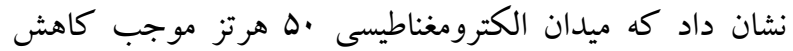
تعداد سلولهاى اسبرماتوزنيك اسبرماتو گونى، اسبرماتوسيت

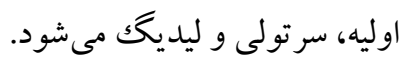

تحقيقاتى كه دربارة اثر حفاظتى فرآوردههاى طبيعى داراى

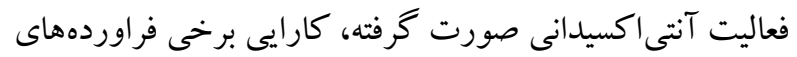
طبيعى در بيشخيرى از آسيبهاى موادشيميايى و ميدانهاى مغناطيسى مختلف را تأئيد كرده است. اثر آنتى اكسيدان تر كيبات طبيعى در كاهش اختلالات ميدانهاى الكترومغناطيسى بررسى شده است؛ نتايج نشان داد كه فراوردههاى طبيعى مى لـى تو اند در خنثى كردن اثرات مضر مواد شيميايى فيزيكى آلايندههاى محيطى مانند ميدانهاى الكترومغناطيسى موثر باشد اثر (2014) Fink و Poljsak .(Zahedifar et al., 2015) حفاظتى آنتى اكسيدانهاى طبيعى را درمقابل آسيبهاى ناشى از آلايندههاى زيستى مورد بررسى قرار داده و نشان دادند كه قرار كيرى در معرض آلايندهاى زيستمحيطى استرس اكسيداتيو را افزايش مىدهد. درمقابل، آنتىاكسيدانها اثر حفاظتى دربرابر استرس اكسيداتيو نشان مىدهند. در گزارشى اثر حفاظتى آنتىاكسيدانهاى ويتامين C و E بر بيضذ آسيبديده ناشى از امواج الكترومغناطيسى تلفن همراه

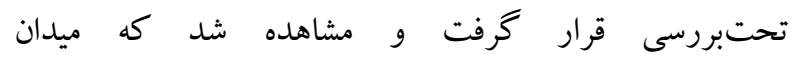
الكترومغناطيسى مى تواند باعث افزايش قطر لولههاى اسبرمساز شود، درحالى كه ويتامين C و E موجب كاهش استرس اكسيداتيو ناشى از امواج الكترومغناطيسى تلفن همراه مئى شود (Al-Damegh, 2012). يافتهاى اين يزوهش نيز نشان داد كه

نتايج اين يزوهش نشان داد كه قراركرفتن درمعرض ميدان

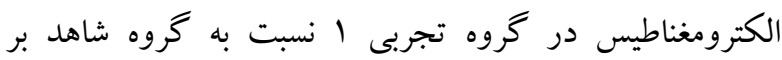
يارامترهايى جون وزن إيديديم، قطر لولههاى منىساز و

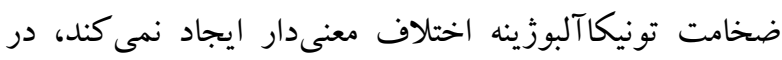
حالى كه به كاهش معنىدار وزن و قطر بيضه، تعداد لولههاى

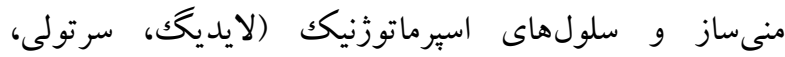

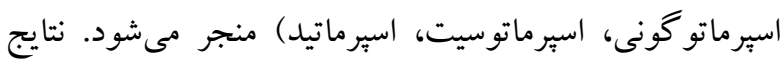
بررسىهاى ما در ساير گروههاى تجربى تحت تأثير عصارئ خياردريايى در مقايسه با گروه تجربى ا، افزايش معنىدار وزن و قطر بيضه را نشان داد. همجنين اثر عصاره خياردريايى منجربه افزايش معنىدار تعداد لولههاى منىساز، تعداد سلولهاى لايديگك، سرتولى، اسبرماتو گونى، اسبرماتوسيت و اسبرماتيد در ساير گروههاى تجربى نسبت به تجربى اشد.

كزارش هاى مختلفى از اثر ميدانهاى الكترومغناطيسى و بررسى

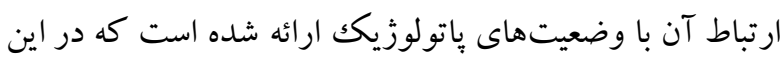
راستا نوع ميدان، شدت، مدت زمان قرار گرفتن درمعرض ميدان در نتايج اين آزمايشات موثر نشان بوده است. براى مثال مثال نشان مران

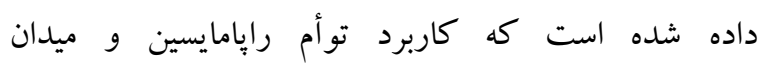
الكترومغناطيسى با فركانس بسيار پايين اثرات مهارى بر

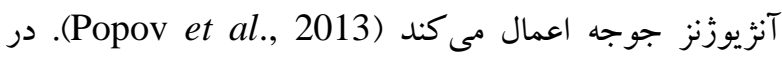

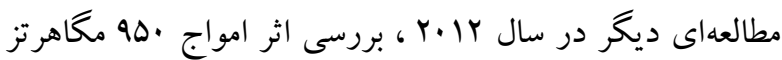

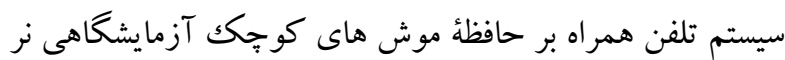
نشان داد كه عملكرد حافظه و تجزيه و تحليل حيوانات در معرض امو اج تلفنهاى همراه، كاهش وابسته به زمان در معرض لهرد قرار گيرى و توان نشان مى دهد (Ibrahim, 2012). دربارهُ تأثير ميدانهاى الكترومغناطيسى بر دستخاه توليدمثل مطالعات نشان دادهاند كه ميدانهاى الكترومغناطيسى مى توانداند

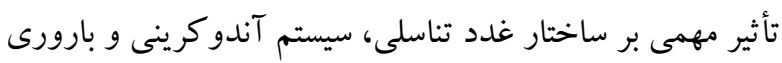
داشته باشند. تحقيقاتى كه با هدف بررسى اثر ميدانهاى الكترومغناطيسى بر بارورى موش نر صورت گرفته است اثرات 
آيويتوز شود كه نشاندهندة اثر حفاظتى خياردريايى بر سلولهاى PC12 و SAMP8 است. در مطالعة ديخرى اثر آنتى -

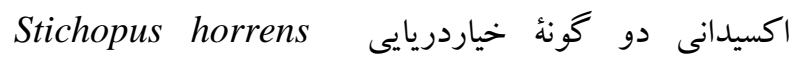
Selenka كرفت و اثر آنتى اكسيدانى اين دو گونه و اثر ضدتكثيرى آن بر

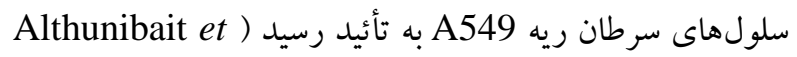

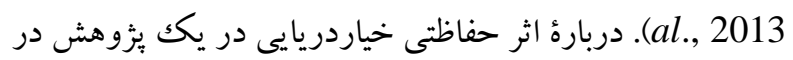

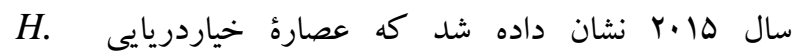
arenicola رتها است كه با يافتهاى يُزوهش حاضر مبنى بر اثر حفاظتى اين گونه خياردريايى مطابقت دارد (Fahmy et al., 2015).

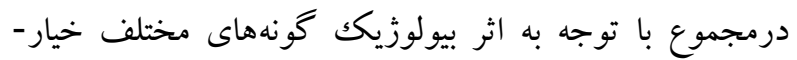
دريايى و متابوليتهاى فعال موجود در آن، اثر حفاظتى عصارةآبى خياردريايى H. arenicola بخشى مرهون خواص آنتىاكسيدانى خياردريايى است كه توانستهاست از آسيب ناشىاز ميدان مغناطيسى •ه هرتز بر بافت بيضه ييشخيرى كند.

\section{نتيجه كيرى}

درمجموع يافتهاى حاصل از اين بزوهش نشان داد كه عصارة خياردريايى بهدليل وجود تركيبات فعال زيستى متنوع داراى اثر

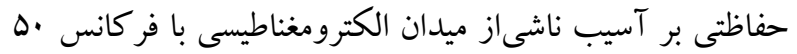
هرتز ازجمله كاهش وزن و قطر بيضه، كاهش تعداد لولههاى منىساز و كاهش تعداد سلولهاى اسبرماتوزنيك غدد جنسى موش نر است كه اين عصاره را ززينهُ مناسبى جهت حفظ

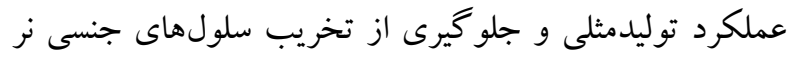
آسيبديده از ميدان مغناطيسى معرفى مى كند.

تقدير و تشكر

از همكاران مركز تحقيقاتى بيولوزى كاربردى تكوين جانورى

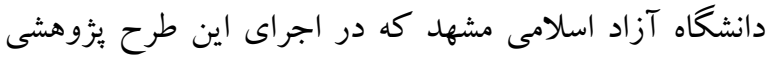
همكارى داشتند قدردانى مى گردد.
عصاره خياردريايى بتانسيل بالايى در بيشگيرى از آسيب ناشىاز ميدان •ها هرتز بر بافت بيضه و لولههاى منى ساز دارد. در زمينهُ يتانسيل آنتىاكسيدانى خاريوستاندريايى كزارشات زيادى در دسترس است (Amini et al., 2015). يخوهشهاى تئى بسيارى بر يتانسيل آنتىاكسيدانى خياردريايى و تركيبات فعال موجود در آن تأكيد كردهاند (Soltani et al., 2015). بنابراين ممكن است در اين يثزوهش اثر حفاظتى عصاره خياردريايى در كاهش اثرات ميدان ·ه هرتز بر روى بيضه، إيبديديم و سلولهاى اسبرماتوزنيكك ناشى از خواص زيستى تركيبات فعال زيستى موجود در عصارة آبى باشد.

مطالعات نشان داده است كه عصاره آبى گونههاى مختلف خياردريايى داراى تركيبات هيدروفيل همجون يلىساكاريد،

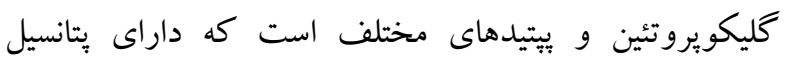
زيستى و دارويى دارند و اثر سيتوتوكسيك، آنتىاكسيدان و

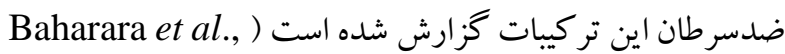
.(2016

تاكنون تحقيقات بسيارى درزمينهُ اثرات خياردريايى صورت

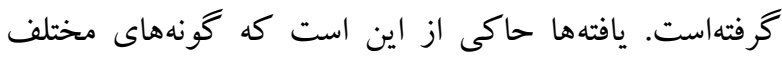

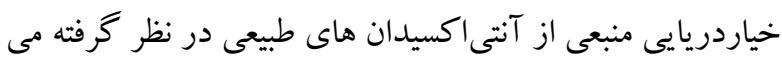

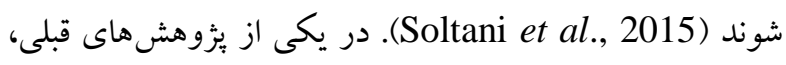

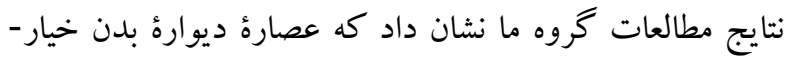
دريايى Holothuria leocospilota به دليل خاصيت آنتى اكسيدانى و افزايش محتواى مواد معلنى در سلولهاى بنيادى

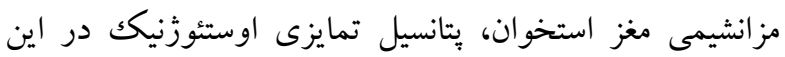
سلولها دارد (Baharara et al., 2014). و و همكاران (2014) اثر حفاظتى خياردريايى گونه

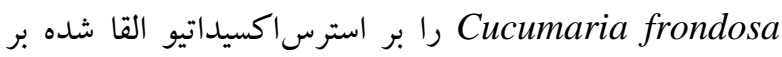
سلولهاى PC12 و مAMP8 موش بررسى كردند و دريافتند كه فعاليت آنتىاكسيدانى خياردريايى ممكن است باعث مهار 


\section{References}

Adams, J.A., Galloway, T.S., Mondal, D., Esteves, S.C. and Mathews, F. 2014. Effect of mobile telephones on sperm quality: A systematic review and meta-analysis. - Environment International 70: 106-112.

Al-Damegh, M.A. 2012. Rat testicular impairment induced by electromagnetic radiation from a conventional cellular telephone and the protective effects of the antioxidants vitamins $\mathrm{C}$ and $\mathrm{E}$. CLINICS 67:785-792.

Althunibat, O.Y., Ridzwan, B.H., Taher, M., Daud, J.M., Jauhari Arief Ichwan, S. and Qaralleh, H. 2013. Antioxidant and cytotoxic properties of two sea cucumbers, Holothuria edulis Lesson and Stichopus horrens Selenka. - Acta Biologica Hungarica 64: 1020.

Amini, E., Nabiuni, M., Baharara, J., Parivar, K. and Asili, J. 2015. Metastatic inhibitory and radical scavenging efficacies of saponins extracted from the Brittle Star (Ophiocoma erinaceus). - Asian Pac. J. Cancer Prev. 16: 4751-4758.

Baharara, J., Amini, E. and Vazifedan, V. 2016. Concomitant use of sea cucumber organic extract and radiotherapy on proliferation and apoptosis of cervical (HeLa) cell line. - Zahedan J. Res. Med. Sci. In Press.

Baharara, J., Amini, E., Namvar, F. and Soltani, M. 2014. The Effect of Persian Gulf sea cucumber alcoholic extract on osteogenic and adipodgenic differentiation of Rat mesenchymal stem cells. Iranian J. Basic Med. Sci. 5: 273-280.

Baharara, J., Ashraf, A.R., Jafari, M.R. and Helalat, H. 2007. The effects of exposure to simulation cell phone waves on gonads of male mouse. - Arak Medical University Journal 10: 8-16.

Baharara, J., Oryan, S. and Ashraf, A.R. 2007. Effects of microwaves $(940 \mathrm{MHz})$ of the ovary and female fertility of Balb/C. - Journal of Tarbiat Moalem University 7: 931-940.

Baharara, J., Parivar, K., Oryan, S. and Ashraf, A. 2006. Effects of low frequency electromagnetic fields on gonads and fertility of female Balb/c mouse. - Arak Medical University Journal 9: 1-11.

Bordbar, S., Anwar, F. and Saari, N. 2011. High-value components and bioactives from sea cucumbers for functional foods. A review. - Marine Drugs 9: 17611805 .

Fahmy, S.R, Amer, M.A and Alkillidar M.H. 2015. Ameliorative effect of the sea cucumber Holothuria arenicola extract against gastric ulcer in rats. - The Journal of Basic \& Applied Zoology 72: 16-25.

Gherardini, L., Ciuti, G., Tognarelli, S. and Cinti, C. 2014. Searching for the perfect Wave: The effect of radiofrequency electromagnetic fields on cells. International Journal of Molecular Sciences 15: 53665387.

Hemayatkhah Jahromi, V., Karimi Jashni, H., Mosallanezhad, M., Mosallanejad, M., Jamali, H, and Izadpanah, P. 2012. The Effect of microwave ovens radiation leakage on testis tissue and sex hormones in immature Mice. - Journal of Fasa University of Medical Sciences 2: 6-11.

Ibrahim, H.A.H. 2012. Antibacterial carotenoids of three Holothuria species in Hurghada. Egyptian. Journal of Aquatic Research 38: 185-194.

Khosravi, F., Valojerdi, M.R., Amanlou, M., Karimian, L. and Abolhassani, F. 2014. Relationship of seminal reactive nitrogen and oxygen species and total antioxidant capacity with sperm DNA fragmentation in infertile couples with normal and abnormal sperm parameters. - First International Journal of Anthology 46: 17-23.

Kumar, P. and Shukla, V. 2014. Ultrastructural changes in Rat testicular tissue after whole body exposure to electromagnetic radiation emitted from mobile phones. - Journal of International Academic Research for Multidisciplinary 2: 518-526.

Li, P., Huo, L., Su, W., Lu, R., Deng, C. and Liu, L. 2011. Free radical-scavenging capacity, antioxidant activity and phenolic content of Pouzolzia zeylanica. Journal of the Serbian Chemical Society 76: 709-717.

Luo, Q., Li, J., Cui, X., Yan, J., Zhao, Q. and Xiang, C. 2014. The effect of Lycium barbarum polysaccharides on the male rats' reproductive system and spermatogenic cell apoptosis exposed to low-dose ionizing irradiation. - Journal of Ethnopharmacol 154: 49-58.

Parivar, K., Nabiuni, M., Golestanian, N. and Amini E. 2011. Effect of low frecuency electromagnetic fields on the spermatogenesis and blood serum protein of Balb/c mice. - Journal Cell Tissue 2: 47-56.

Poljšak, B. and Fink, R. 2014. The Protective role of antioxidants in the defence against ROS/RNS-mediated environmental pollution. - Oxidative Medicine and Cellular Longevity 2014: 1-22.

Popov, A., Artyukov, A., Krivoshaoko, O. and Kozlovskaya, E. 2013. Biological activities of collagen 
peptides obtained by enzymic Hydrolysis from FarEastern holothurians. - American Journal of Biomedical and Life Sciences 1: 17-26.

Roshangar, L. and Hamdi, B.A. 2014. Effect of lowfrequency electromagnetic field exposure on oocyte differentiation and follicular development. - Advanced Biomedical Research 3: 1-76.

Soltani, M., Parivar, K., Baharara, J., Kerachian, M.A. and Asili, J. 2015. Putative mechanism for apoptosis-inducing properties of crude saponin isolated from sea cucumber (Holothuria leucospilota) as an antioxidant compound. - Iranian Journal of Basic Medicine Sciences 18: 180-187.

Wu, F.J., Xue, Y., Liu, X.F., Xue, C.H., Wang, J.F. and Du, L. 2014. The protective effect of eicosapentaenoic acid-enriched phospholipids from sea cucumber Cucumaria frondosa on oxidative stress in PC12 cells and SAMP8 mice. - Neurochem. Inter. 64: 9-17.

Zahedifar, Z., Baharara, J., Branch, M. and Branch M. 2015. Effect of green tea in decreasing electromagnetic waves damages. - Zahedan J. Res. Med. Sci. 17:29-34.

Vasei, N., Baharara, J., Zafar Balanezhad, S. and Amini., E. 2015. An investigation of the protective impact exerted by aqua extract of Persian Gulf sea cucumber (Holothuria arenicola Semper, 1868) against damages induced by electromagnetic field on male gonads of Balb/C mice. - Nova Biologica Reperta 2: 216-226.

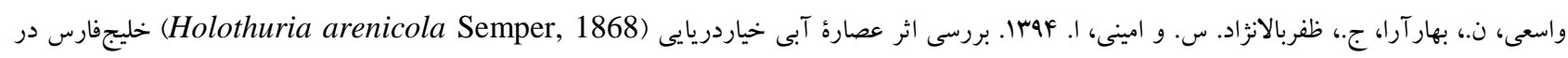

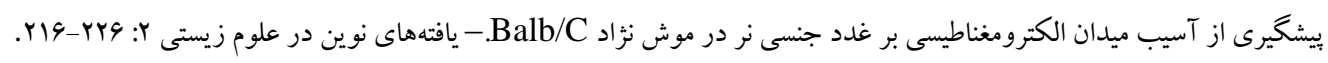


